\title{
Analysis on the Ecological Model of Business English Translation Teaching
}

\author{
Aina Sun \\ Nanfang College of Sun Yat-sen University, Guangzhou, Guangdong, 510970, China
}

Keywords: Business English; translation teaching; ecological model

\begin{abstract}
With the rapid development of multimedia technology and Internet, business English translation teaching has developed accordingly, and various teaching modes are constantly emerging. However, there are still some problems in its development. This paper mainly analyzes the problems existing in the teaching process of business English translation from the perspective of ecology and put forward strategies and methods of ecological class construction of business English translation from the aspects of teaching content, methods and objectives.
\end{abstract}

\section{Introduction}

The current research on business English translation teaching in our country mainly focuses on business translation skills, business text characteristics and the improvement of translators' abilities, while little analysis and research on it are made from the perspective of ecological model. The ecological environment of education is closely related to the effect of teaching. Therefore, it is necessary to analyze and discuss the problems of business English translation teaching from the Ecology principles that conform to the laws of Ecological Education.

\section{Analysis of Cremin Lawrence}

Ecology mainly refers to the integration of environment and biology in a certain space in nature, in which environment and biology restrict and influence each other and are in a relatively stable state of dynamic equilibrium in a certain period. Nowadays, the principles, thoughts and methods of ecology have been gradually extended to all fields of society, so is pedagogy. People have already begun to pay attention to class teaching and education from the perspective of ecology, thus Cremin Lawrence has gradually derived.

The research on Cremin Lawrence originated at first in the West at mainly based on the study of human behavior. With the rapid development of education career in our country, the research on Cremin Lawrence is also gradually showing a booming momentum. Moreover, the quality and quantity of the research continue to rise, and the scope of research is also wider ${ }^{[1]}$. Groups of scientific research workers and educational theory researchers have integrated the theme of ecology into specific disciplines of onlooker discipline to conduct in-depth research on the relationship between education and the ecological environment. In recent years, scholars and researchers in foreign language discipline have begun to focus on the ecological problems in foreign language discipline education, opening up a new field of foreign language research.

Business English translation course is a very important part of business English course, and it is obviously different from other courses. First, business English translation class involves bilingual culture, thus constituting a relatively unique ecological environment. Then there has always been controversy as to whether business English should focus on students or teachers. Student oriented refers to students' main practice in the actual class teaching process, followed by teachers' teaching, while teacher-oriented refers to teachers' main interpretation of translation skills and knowledge in the actual class.

\section{Main Problems in Business English Translation Teaching}

One of the most important links in the curriculum is the teaching objective, which plays a 
decisive role in teaching evaluation, teachers' and students' roles and teaching methods. At present, translation courses have been set up in business English majors in various colleges and universities in our country, but the teaching objectives of this course are not the same ${ }^{[2]}$. Some colleges and universities have set up their teaching objective as improvement of the cross-cultural communication ability of their students, while others have set up their teaching objective as improvement of the English level of their students through translation exercises. The main reason why the teaching objectives are not clear is that the business English translation teaching cannot be arranged as a whole and the syllabus seriously lacks. Thus, the business English translation course's teachers are only able to set up the teaching objectives based on their own experience in the teaching process, thus inevitably causing problems such as duplication of knowledge points and disorder. This not only seriously affects students' learning initiative, but also wastes a lot of time.

The current content of business English translation teaching in our country is relatively old, which is further out of touch with the times. Its publication is relatively early, so the teaching content used is very difficult to keep up with the rapid development of the times. With the changes of the times, great changes have taken place in the textual and linguistic features of business texts. However, due to the fact that the teaching materials of business English translation courses cannot be updated in time, the knowledge learned by students in the class is not consistent with the actual translation. At the same time, the quality of the teaching materials for business English translation courses is also different. Because of the relatively short preparation time, some teaching materials are patched pieces by pieces together, the content of them is difficult to form a system, which is not conducive to the actual learning of students.

Traditional and outdated teaching methods are still used in the current business English translation classes in our country. Teachers help students to translate and understand the characteristics, specific translation skills and theoretical knowledge of translation through explanation and practice. The explanation method plays an important role in the internalization of knowledge, but it also brings a lot of problems to teaching ${ }^{[3]}$. First, the atmosphere in class is rather dull and it is difficult to arouse the enthusiasm of the students. Then, this method focuses on the teachers, thus the students' autonomy is very poor. Next, teachers pay too much attention to the explanation of skills and neglected to help students adjust their thinking and adapt to the conversion process in the process of business English translation. The essence of business English translation is the flexible conversion between languages. This kind of transformation requires not only language knowledge but also thinking. In a teacher-centered teaching class, the training of students' thinking transformation is rarely involved, thus making students unable to flexibly carry out the knowledge they have learned in the actual translation process.

\section{Effective Strategies for Construction of Ecological Business English Translation Classes}

The ecological syllabus pays more attention to the combination of translation theory and business expertise, the establishment of an ecological teaching environment, and the arrangement of learning objectives based on the actual needs of students. The ecological teaching syllabus clearly defines the teaching objectives so that business English translation teachers can clearly understand the teaching methods, process and contents. Teachers are also encouraged to explain translation knowledge and skills according to the requirements of students at different learning stages, and to reasonably integrate problem knowledge, language knowledge and business professional knowledge into the explanation of translation skills and theories so as to fully reflect the scientific, systematic and comprehensive characteristics of business English translation courses. Most of the recipients and users of business English texts are not people in the business field, and the content involved in business English is very formal and serious. Therefore, in the actual translation process, teachers must guide students to accurately grasp the translation and clarify their own teaching objectives, for example, in General cargo vessels: A vessel designed to handle break bulk cargo bags, cases, carts, drums and crates. In this article, the words such as boxes, cardboard boxes and parcels are all professional terms, so in the actual translation process, translation of terminology must be accurate. At the same time, it also involves the polysemy of a word, which requires the translator to have a 
strong foundation of professional knowledge. In the process of guiding this translation, teachers need to clarify their own teaching objectives and know what they should teach students.

The failure to keep pace with the times in the content of the teaching materials is an important factor that leads to the disconnection between the teaching content of the business English translation course and the actual translation. So, teachers should try their best to choose the new edition or reprinted edition of teaching materials when choosing teaching materials, so as to ensure that the content of teaching materials is carried out first ${ }^{[4]}$. In addition, we must also attach importance to the authority of the selected teaching materials. Nowadays, there are many kinds of business English teaching materials, many of which are pieced together at will, not only the quality level is not uniform, but also the content is not ensured to be systematic. In order to effectively ensure the accuracy, systematicness and real-time nature of the teaching content of business English translation courses, the latest teaching materials of professional or famous publishers can be selected, and at the same time the teaching materials designated by the state can be directly selected.

In the actual teaching process of business English translation, multimedia and other technologies can also be reasonably applied to assist teaching, and video and audio files can be used to show students the translation situations they are likely to encounter in their future work. Through a large number of practical connections, students can realize translation practice more clearly, and their own translation creation ability can also be effectively improved. For example, in the teaching process of business card translation, this is also a problem often encountered in business communication, and teachers can use multimedia to play related videos to students, and then let students do video situation imitation, so as to improve their translation practice ability. In addition, students can also improve their translation creation ability through adaptation, rewriting and excerpting, and encourage them to learn more knowledge except their major. This can also effectively improve their translation ability.

The main requirement of business English translation is to ensure that the language conforms to the standard and is natural and fluent. First, it is necessary to convey the original meaning of the language. In the process, it is also inevitable to add some words. Through the increased use of notional words and form words, the translated language can be more complete and the original meaning can be preserved at the same time. For example, in the translation teaching of the content: Currently we are working with 19 enterprises and every year we are adding between ten and twenty investments to our client list, teachers can guide students to use a variety of translation techniques to carry out translation. For example, currently we are working with 19 enterprises and every year we are adding between ten and twenty invest-ments to our client list. This translation is very indirect, but at the same time it can retain the original meaning and be concise. At the same time, it can also be translated in its original form. This not only can effectively improve the quality of business English translation teaching, but also can effectively improve students' translation thinking ability, so that they can carry out translation more flexibly in their future positions.

\section{Conclusion}

In short, the main goal of the business English translation course is to provide practical translation talents for the society. At present, there are many problems in the business English translation curriculum in our country, so it is necessary to have business English teachers and experts in various fields continuously analyze and discuss them. However, whether in terms of teaching methods or teaching contents, the solution must be around the goal of delivering qualified translators to the society.

\section{Acknowledgment}

The research is funded by Major Scientific Research Programs of Guangdong Province (2016GXJK216) and the Teacher’s Team of Innovation of Guangdong Police College. 


\section{References}

[1] Chu Lingyun. Research on Ecological Mode of Business English Translation Teaching [J]. Teaching of Forestry Region, 2016(1):48-49.

[2] Zhu Huifen. Theoretical and Practical Research on Business English Translation from the Perspective of Ecology [M]. Beijing Institute of Technology Press, 2013.

[3] Fu Youyou, Cheng yuan. Analysis of the Learning Effect of Business English Translation under ESP teaching mode [J]. Qunwen Tiandi, 2012(1):176-176.

[4] Guo Shanshan, Liu Yan. Feasibility Analysis of Business English Translation Cooperative Learning Teaching Model [J]. Journal of Guangdong Normal University of Technology, 2012 (11): 139-143. 